\title{
Factors Influencing GAP-43 Gene Expression in PC12 Pheochromocytoma Cells
}

\author{
B. Costello, A. Meymandi, and J. A. Freeman \\ Department of Cell Biology, Vanderbilt Medical School, Nashville, Tennessee 37232
}

\begin{abstract}
We have studied factors controlling message levels for the neuronal growth- and plasticity-associated protein, GAP-43. Following exposure of PC12 cells to various effectors, cytoplasmic RNA was isolated and analyzed by Northern transfer and autoradiography using a GAP-43 cDNA probe. Induction by NGF is apparent after $3 \mathrm{hr}$ exposure and reaches maximal levels at $24 \mathrm{hr}$. Beyond $24 \mathrm{hr}$, levels remain constant in the continued presence of NGF. Induction is insensitive to variations in culture conditions, such as plating density or substrate, which influence NGF-induced neurite outgrowth. Other inducers, in order of decreasing efficacy, are FGF, dBcAMP, TPA, $\mathrm{K}^{+}$, and EGF. Insulin and retinoic acid are ineffective. Dexamethasone partially inhibited basal expression as well as induction by NGF, FGF, dBCAMP, and TPA. The methyltransferase inhibitor 5'-S-(2-methyl-propyl)adenosine completely inhibited induction by NGF, FGF, and dBCAMP. Inhibition of protein synthesis by cycloheximide partially decreased induction by NGF, FGF, and TPA but slightly enhanced dBCAMP induction. Complete downregulation of protein kinase $C$ by chronic TPA treatment completely eliminated the TPA response but slightly enhanced induction by NGF. These findings and the results of additivity experiments in which cells were stimulated with various combinations of NGF, dBcAMP and TPA suggest that NGF induction of GAP-43 RNA (1) does not involve activation of protein kinase $C$ but (2) may be mediated partially via activation of protein kinase $A$.
\end{abstract}

GAP-43 is a neuron-specific protein which exhibits elevated synthesis and axonal fast-transport during development and nerve regeneration (reviewed in Snipes et al., 1987b; Benowitz and Routtenberg, 1987; Skene, 1989). Correlation of increased GAP-43 expression with axonal growth has been demonstrated in the CNS of fish (Benowitz et al., 1981; Freeman et al., 1986), amphibians (Skene and Willard, 1981a), and neonatal mammals (Skene and Kalil, 1984; Freeman et al., 1986). Similar increases rclative to normal mature nerves are seen in mammals in the developing CNS (Skene and Willard, 1981 b; Freeman et al., 1986) and in the regenerating PNS (Skene and Willard, 1981b). Increased expression also is observed in cultured neurons when maintained under conditions which promote neurite outgrowth (Perrone-Bizzozero et al., 1986). In contrast, increased expres-

\footnotetext{
Received July 12, 1989; revised Oct. 26, 1989; accepted Oct. 27, 1989.

We are grateful to Drs. Jeanette J. Norden, Andrew Lettes, and Li-Hsien Lin for helpful comments on the manuscript and to Dr. Benjamin Wouters for preparing the figures. This work was supported by NIH grant NS18103 to J.A.F.

Correspondence should be addressed to Dr. Brian Costello at the above address. Copyright @ 1990 Society for Neuroscience $0270-6474 / 90 / 041398-09 \$ 02.00 / 0$
}

sion has not been observed following injury to the CNS of higher vertebrates where axonal regeneration does not occur (Skene and Willard, 1981b).

Temporal and spatial changes in GAP-43 content and localization in brain also are positively correlated with neuronal growth. The levels and rates of synthesis of GAP-43 in rat cerebellum and cerebral cortex are about 10 -fold greater in neonates compared with adults (Jacobson et al., 1986). During development, GAP-43 is localized to growing neuronal processes, while in the mature brain it is present in most neuropil areas and is especially rich in structures exhibiting synaptic plasticity (Rosenthal et al., 1987; McGuire et al., 1988). Consistent with this latter observation, elevated levels of GAP-43 transcripts are observed in cell bodies of neurons synapsing in plastic areas of the adult brain (Neve et al., 1987; Rosenthal et al., 1987). This observation, together with the greater cell-free translation of GAP-43 from polyadenylated RNA isolated from neonatal compared with adult cortex (Jacobson et al., 1986), suggests that the growth- and plasticity-associated changes in GAP-43 synthesis rate and steady-state levels are mediated through changes in its mRNA levels.

The recent identification of GAP-43 with the independently studied neuronal phosphoproteins F1, B-50, and pp46 (Basi et al., 1987; Karns et al., 1987; Nielander et al., 1987; Rosenthal et al., 1987; Snipes et al., 1987a) suggests that its function in synaptic plasticity may be dependent on posttranslational modification, as well as its level of expression. Induction and maintenance of long-term potentiation in the hippocampus is correlated specifically with increased phosphorylation of protein F1 (Routtenberg et al., 1985). This change in Fl (GAP-43) phosphorylation suggests that it may play a direct role in the processes underlying synaptic plasticity. Hence, high levels of GAP-43 expression in certain areas of the adult brain may be a prerequisite for synaptic plasticity which is modulated in a rapid, activity-dependent fashion by altering GAP-43 phosphorylation. The observation that phosphorylation of B-50 (GAP43) by protein kinase $C$ also is involved in plasma membrane polyphosphoinositide metabolism (Jolles et al., 1980; Van Hoof et al., 1988) is intriguing, but the relationship of this effect to neuronal growth remains unclear.

Although the correlation of elevated GAP-43 expression with neuronal growth states is well established, the specific factors which control its expression are poorly understood. In recent work from our laboratory and others, the PC12 line of pheochromocytoma cells has been used to study GAP-43 regulation. These cells are very useful for such studies since NGF stimulation causes them to cease dividing and undergo a program of neuronal differentiation which includes neurite outgrowth (Greene and Tischler, 1976). NGF also causes a concomitant 
increase in GAP-43 expression (Van Hoof et al., 1986; Costello et al., 1987). Furthermore, the localization of GAP-43 to growth cones in NGF-treated PC12 cells (Van Hoof et al., 1986; Costello et al., 1987) is very similar to that seen in cultured neurons (Meiri et al., 1986, 1988) and suggests that GAP-43 is serving the same growth-associated function in both cases. These findings, together with the obvious advantages of using a cell line, make PC12 cells an excellent model for studying the molecular mechanisms underlying GAP-43 expression.

In this report we have extended our previous observations on NGF induction of GAP-43 message in PC12 cells (Costello et al., 1986; Costello and Freeman, 1988). We have characterized this NGF response in terms of its time course, dose-response relationship, sensitivity to variations in culture conditions which affect neurite outgrowth, dependence on protein synthesis, and sensitivity to methyltransferase inhibitors and glucocorticoid. Many of these parameters also were examined for a number of other agents that are capable of influencing gene expression. Several of these were found to increase GAP-43 expression, although none was as effective as NGF. Finally, our results allow us to draw some conclusions regarding the mechanisms underlying NGF induction of GAP-43.

\section{Materials and Methods}

Cell culture. In general, $\mathrm{PC} 12$ cells were grown on tissue culture plastic in $85 \%$ RPMI $1640,10 \%$ heat-inactivated horse serum, $5 \%$ fetal calf serum as outlined by Greene and Tischler (1976). They were maintained at $37^{\circ} \mathrm{C}$ in an atmosphere of $92.5 \%$ air, $7.5 \% \mathrm{CO}_{2}$. Two days prior to the start of an experiment, cells were plated at $40,000 / \mathrm{cm}^{2}$. In some experiments, variations in this standard protocol were used, as explained in the text and figure legends. All effectors were added to cells as stock solutions in medium, except dexamethasone and retinoic acid, which were added as $\mathrm{EtOH}$ stocks, and 12-O-tetradecanoylphorbol-13-acetate (TPA) and 5'-S-(2-methyl-propyl)adenosine (SIBA) which were added as DMSO stocks. Final vehicle concentrations (vol/vol) were dexamethasone $(0.1 \%)$, retinoic acid $(0.25 \%)$, TPA $(0.2 \%)$, and SIBA $(0.2 \%)$. Ethanol up to $0.25 \%$ did not alter basal or NGF-stimulated GAP-43 expression. However, DMSO did have a slight inhibitory effect. Therefore, GAP-43 RNA contents for cells treated with TPA or SIBA were normalized to take account of this effect. (Untreated cells and cells treated with $100 \mathrm{ng} / \mathrm{ml} \mathrm{NGF}$ showed the same proportional decrease in GAP-43 RNA content in the presence of $0.2 \%$ DMSO.) Except as noted, cells were exposed to effectors for $24 \mathrm{hr}$ prior to RNA isolation. All experiments were repeated at least twice with qualitatively similar results in all cases. 7S NGF was isolated from mouse submaxillary glands as outlined by Burton et al. (1978). Bovine insulin, TPA, N6$2^{\prime}$ - $O$-dibutyryladenosine $3^{\prime}: 5$ '-cyclic monophosphate (dBcAMP), SIBA, cycloheximide and retinoic acid (all trans) were obtained from Sigma (St. Louis, MO). Fibroblast growth factor (FGF) and epidermal growth factor (EGF), derived from bovine pituitary and from mouse submaxillary glands, respectively, were purchased from Calbiochem (San Diego, CA).

RNA isolation and Northern blot analysis. Cells were pelleted by centrifugation, resuspended in hypoosmotic buffer $(10 \mathrm{~mm}$ Tris- $\mathrm{Cl}, \mathrm{pH} 7.4$; $10 \mathrm{mM} \mathrm{NaCl} ; 0.15 \mathrm{mM} \mathrm{MgCl} 2$ ), and lysed by addition of NP-40 to $1 \%$. After pelleting nuclei, the supernatant was subjected to proteinase $\mathrm{K}$ digestion followed by phenol/chloroform extraction. All RNA isolation steps prior to proteinase $\mathrm{K}$ digestion were performed at $0-4^{\circ} \mathrm{C}$. Samples were analyzed by electrophoresing $10 \mu \mathrm{g}$ per lane in $1.2 \%$ agarose gels containing $2.2 \mathrm{~m}$ formaldehyde. Following electrophoresis, gels were stained with ethidium bromide and photographed under UV illumination. Negatives were scanned (see below) in order to compensate for loading differences among lanes. RNA was transferred to nylon blotting membranes (Zeta-Probe; Bio-Rad, Richmond, CA) using 10× SSPE, and transfer efficiency was checked by examining gels for ethidium fluorescence. Membranes were hybridized with a ${ }^{32} \mathrm{P}$-labeled probe, produced by nick-translating (using random primers) a purified $1.1 \mathrm{~kb}$ GAP43 cDNA (Karns et al., 1987). They were washed to a stringency of $0.1 \times$ SSPE, $0.1 \% \operatorname{SDS}\left(55^{\circ} \mathrm{C}\right)$ and used to expose Kodak XAR- 5 film at $-70^{\circ} \mathrm{C}$ using intensifying screens. The resulting autoradiographs were
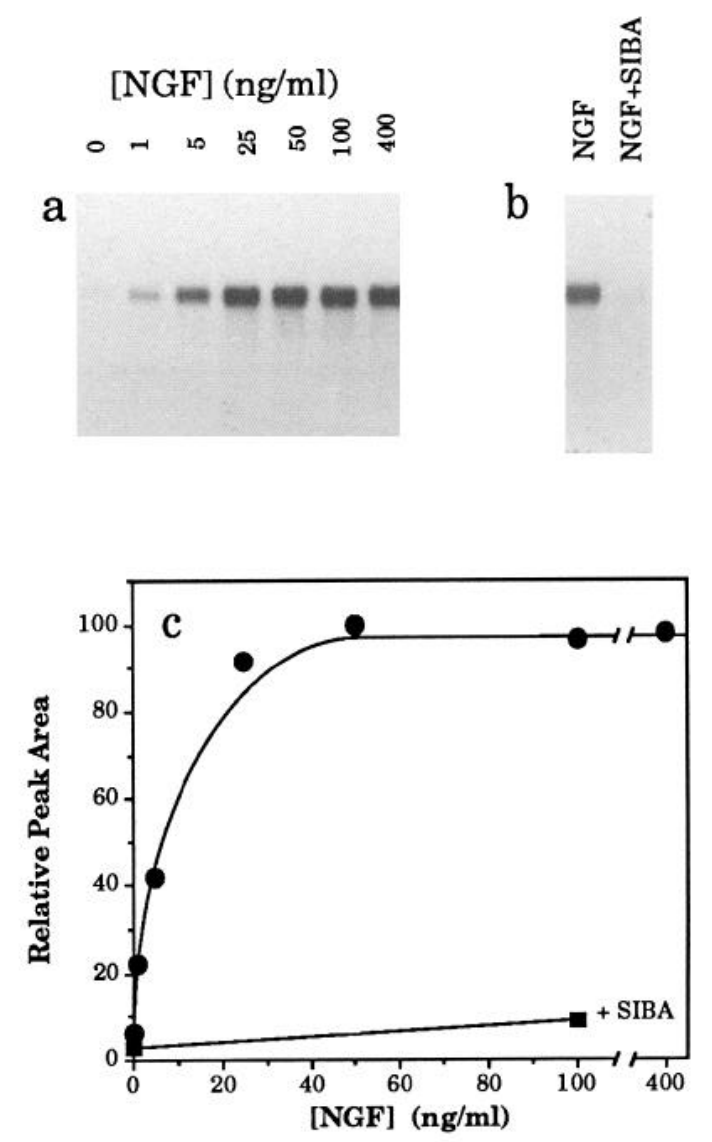

Figure 1. Dose-response relationship for NGF induction of GAP-43. Cells were treated for $24 \mathrm{hr}$ (a period within which steady-state levels of GAP-43 RNA were achieved) with increasing concentrations of NGF. Cytoplasmic RNA was isolated and analyzed by Northern transfer. The resulting autoradiograph $(a)$ was quantitatively analyzed (see Materials and Methods) to produce the dose-response curve $(c$, circles). Inhibition of NGF induction by simultaneous treatment with the methyltransferase inhibitor SIBA also is shown ( $c$, squares). In this case, cells were pretreated with $3 \mathrm{~mm}$ SIBA for $30 \mathrm{~min}$ prior to exposure to 0 or $100 \mathrm{ng} /$ $\mathrm{ml} \mathrm{NGF}$ for $24 \mathrm{hr}$ in the continued presence of SIBA. Part $b$ is the corresponding autoradiograph showing this effect of SIBA on induction by $100 \mathrm{ng} / \mathrm{ml} \mathrm{NGF}$.

analyzed using a computer-interfaced gel scanning system (Technology Resources, Nashville, TN). Representative experiments are presented as graphs reporting relative peak area (total optical density, corrected for background), in arbitrary units, of the GAP-43 band of each sample.

The reliability of these measurements was determined in 2 ways. First, multiple autoradiographic exposures were always obtained in order to ascertain that peak densities were within the linear range of the X-ray film. In addition, the reliability of our analytical procedure was tested by producing standard curves using varying amounts of cytoplasmic RNA from NGF stimulated cells. These curves covered the range of GAP-43 RNA content observed in our experimental samples. Four curves were produced and analyzed separately using the same set of standard samples. In all cases, the curves were linear over their entire range (correlation coefficient $>0.99$ ). Therefore, our analytical procedure provides a faithful and reproducible measure of relative GAP-43 message content.

\section{Results}

Induction by NGF

Following NGF stimulation, PC12 cells have increased levels of GAP-43 protein (Costello et al., 1986; Van Hoof et al., 1986) and RNA (Basi et al., 1987; Karns et al., 1987). Figure 1 shows 


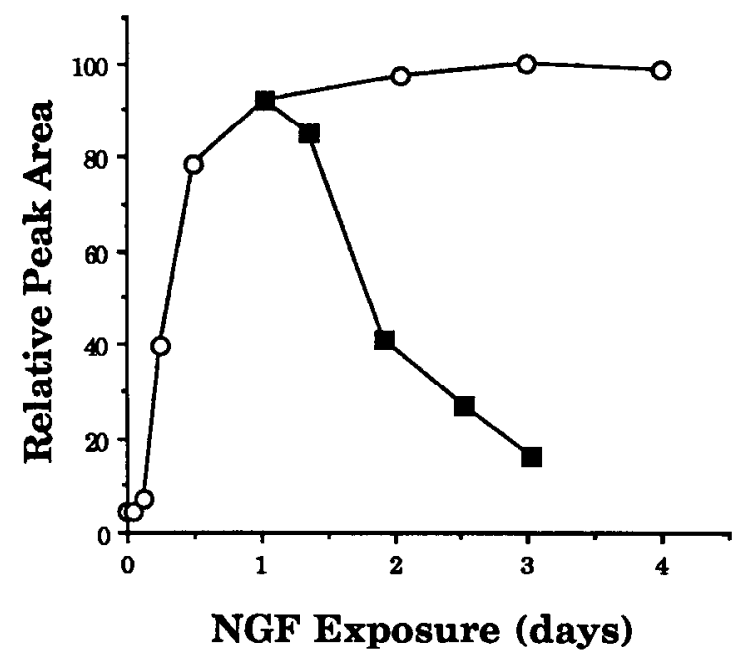

Figure 2. Time course of GAP-43 induction by NGF. Cells were stimulated with $100 \mathrm{ng} / \mathrm{ml} \mathrm{NGF}$ for various timcs prior to isolation of cytoplasmic RNA (open circles). Another set of dishes was treated with NGF for $24 \mathrm{hr}$, at which time NGF-containing medium was removed and dishes were rinsed with NGF-free medium and maintained for various periods thereafter in the absence of NGF (closed squares). The decay curve yields a $t_{1 / 2}$ of approximately $20 \mathrm{hr}$.

GAP-43 RNA levels as a function of NGF concentration. At 1 $\mathrm{ng} / \mathrm{ml}$, the lowest concentration tested, message is already induced approximately 3.5 -fold. Half-maximal induction occurs at an NGF concentration of about $5 \mathrm{ng} / \mathrm{ml}$. At $50 \mathrm{ng} / \mathrm{ml}$, the level of GAP-43 message is 15 -fold greater than in unstimulated cells. Additional increases in NGF concentration do not increase the message level further. Since methyltransferase inhibitors have been shown to block all tested responses of PC1 2 cells to NGF (Seeley et al., 1984), we examined the effect of one such compound, SIBA, on GAP-43 induction. At $3 \mathrm{~mm}$, a concentration which is maximally effective at blocking other NGF actions, SIBA decreases the already very low basal expression and completely inhibits induction by $100 \mathrm{ng} / \mathrm{ml}$ NGF (Fig. 1). The time course of induction also was examined using a maximally stimulating concentration of NGF (Fig. 2). GAP-43 message just begins to be detectable above basal levels after $3 \mathrm{hr}$ treatment with $100 \mathrm{ng} / \mathrm{ml} \mathrm{NGF}$. By $24 \mathrm{hr}$, maximal message levels are reached and are maintained in the continued presence of NGF. When NGF stimulation is withdrawn after $24 \mathrm{hr}$ treatment, GAP-43 message decays fairly rapidly, being decreased by $50 \%$ by $20 \mathrm{hr}$ after withdrawal of NGF. However, this is an overestimate of the message half-life since there is a brief lag before message begins to decrease following NGF removal. This lag can be attributed to incomplete flushing of unbound NGF from the cultures and to the rather slow dissociation $\left(t_{1 / 2}\right.$ of 30 min) of NGF from high-affinity receptors (Landreth and Shootcr, 1980). Since NGF stimulation increases the levels of GAP43 message and protein, and GAP-43 expression has been correlated with axon growth, we were interested in determining whether conditions which affect neurite growth in PC12 cells might influence NGF-stimulated GAP-43 expression. To test this, GAP-43 RNA was measured in cells grown on 3 different substrates that differ in their ability to support cell adhesion and neurite outgrowth: untreated glass (very poor adhesion with many cells in suspension, no neurites), untreated tissue culture plastic (good adhesion, poor neurites), and collagen-coated plastic (very good adhesion, good neurites). In addition, we grew cells on our standard substrate, untreated tissue culture plastic, but at a density of $500,000 / \mathrm{cm}^{2}$, about 6 times our standard cell density of $80,000 / \mathrm{cm}^{2}$. Neurite outgrowth is inhibited at such high densities. Nevertheless, none of these culture variations had any effect on NGF-induced GAP-43 message levels (not shown). These observations contrast sharply with the very strong inhibition of NGF induction of another neuronal gene, SCG 10, in PC1 2 cells grown at high density (Stein et al., 1988). Clearly, NGF-stimulated elevation of GAP-43 message is not generally sensitive to conditions which preclude neurite outgrowth.

\section{Effector survey}

Several other factors in addition to NGF have been shown to control expression of some genes in PC12 cells (Greenberg et al., 1985; Kruijer et al., 1985; Leonard et al., 1987; Stein et al., 1988). Since GAP-43 expression might also be under multiple regulation, an effector survey was done (Fig. 3). Among the reagents tested, only insulin and retinoic acid were without effect, and only dexamethasone inhibited expression. The remaining reagents, which included FGF, EGF, dBcAMP, TPA, and $\mathrm{K}^{+}$, all stimulated expression to varying degrees, with $\mathrm{NGF}$ having the greatest efficacy. It is interesting to note that among these agents there is a general correlation between their efficacies for induction of GAP-43 and for stimulation of neurite outgrowth.

The full dose-response relationships for some of these inducers are shown in Figure 4. Induction by FGF closely resembles that by NGF, being robust, saturable, and inhibited by SIBA. Control of neuronal gene expression by FGF is of special interest since it has been shown to promote survival of, and neurite outgrowth from, CNS neurons (Morrison et al., 1986; Walicke et al., 1986; Walicke, 1988). Half-maximal induction by FGF occurs at about $4 \mathrm{ng} / \mathrm{ml}$; maximal induction is about 11 -fold. In contrast, the more modest inductions by $\operatorname{EGF}(2 \times)$, TPA $(3.5 \times)$, and dBcAMP $(5.5 \times)$ show broad concentration optima. TPA and dBcAMP are believed to exert their effects via activation of protein kinases $C$ and $A$, respectively (Walsh et al., 1968; Nishizuka, 1984). The diminished response to higher TPA concentrations is probably due to down regulation of kinase C (Matthies et al., 1987). For the same reason, the rather modest maximal induction of 3.5-fold is likely an underestimate, and the optimal TPA concentration $(0.1 \mu \mathrm{M})$ is an approximation. The broad, shallow dose-response relationship for EGF, with maximal induction occurring at $1-3 \mathrm{ng} / \mathrm{ml}$, is quite similar to that seen for several other EGF effects on PC1 2 cells such as the inductions of substrate adhesion (Chandler and Herschman, 1980), ornithine decarboxylase activity (Guroff et al., 1981), and the rapid response genes (Greenberg et al., 1985). EGF induction displays little or no inhibition by SIBA. This also is consistent with past work showing that a range of EGFdependent responses in PC12 cells are either enhanced or unaffected by methyltransfcrasc inhibitors (Seeley et al., 1984). In contrast, induction by $\mathrm{dBcAMP}$ is strongly inhibited by SIBA and, in this respect, is similar to the NGF and FGF inductions. We did not observe a consistent effect of SIBA on induction by TPA.

\section{Inhibition of GAP-43 induction by dexamethasone}

Since PC1 2 cells are derived from an adrenal medullary tumor, they resemble chromaffin cells in many respects, including their 


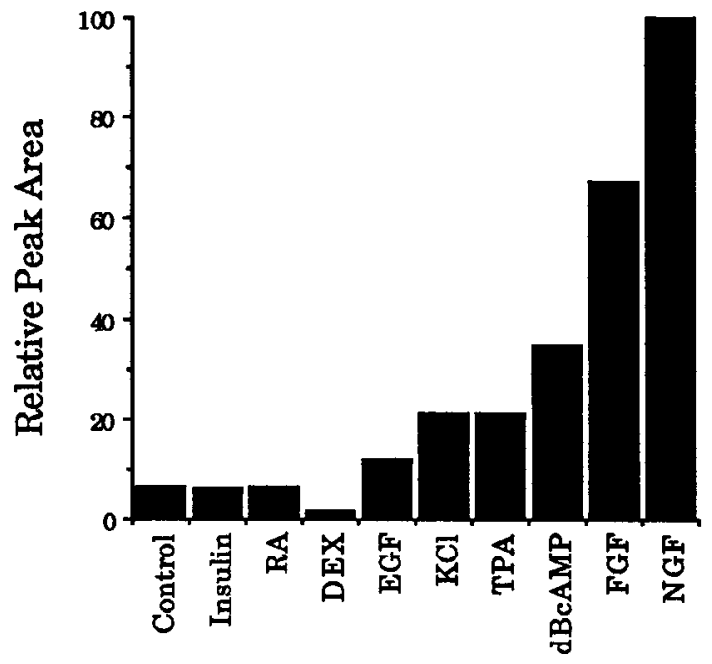

Figure 3. Effector survey. Cells were exposed to the indicated reagents for $24 \mathrm{hr}$ prior to isolation of cytoplasmic RNA. Concentrations of reagents were: insulin $(5 \mu \mathrm{g} / \mathrm{ml})$, retinoic acid $(R A ; 50 \mathrm{nM})$, dexamethasone $(D E X ; 1 \mu \mathrm{M}), \mathrm{EGF}(1 \mathrm{ng} / \mathrm{ml}), \mathrm{KCl}(40 \mathrm{mM}), \mathrm{TPA}(0.1 \mu \mathrm{M}), \mathrm{dBcAMP}$ $(1 \mathrm{mM}), \mathrm{FGF}(40 \mathrm{ng} / \mathrm{ml})$, and NGF $(100 \mathrm{ng} / \mathrm{ml})$. For determination of the $\mathrm{KCl}$ effect, cells were grown in medium which was $75 \%$ normal growth medium (see Materials and Methods) $+25 \% 160 \mathrm{mM} \mathrm{KCl}$, or $75 \%$ normal growth medium $+25 \% 160 \mathrm{~mm} \mathrm{NaCl}$ as control. This control medium had no effect on basal GAP-43 expression compared to $100 \%$ normal growth medium. sensitivity to glucocorticoids (Green and Tischler, 1982). Several glucocorticoids, including dexamethasone, inhibit expression of GAP-43 in PC12 cells (Costello and Freeman, 1988; Federoff et al., 1988). This effect was examined further by treating cells for $24 \mathrm{hr}$ with various concentrations of dexamethasone, followed by another $24 \mathrm{hr}$ in dexamethasone with or without NGF (Fig. 5). Both basal and NGF-stimulated expression of GAP-43 message are maximally inhibited at or above $0.1 \mu \mathrm{M}$ dexamethasone. While basal levels are decreased by approximately $75 \%$, NGF-stimulated levels are decreased by only about $30 \%$. This result differs quite substantially from that reported by Federoff et al. (1988), who observed almost complete dexamethasone inhibition of GAP-43 expression in the presence of NGF. This may represent a clonal difference between our cells and theirs since they reported a 3- or 4-fold increase in GAP43 message in the presence of NGF alone, while we routinely observe inductions of 12 - to 16 -fold. The effect of dexamethasone on GAP-43 induction by other factors also was investigated (Fig. 6). Inhibition of FGF induction is essentially identical to that of NGF, being decreased by approximately one-third. However, the weaker inductions by TPA and dBcAMP are both inhibited by as much as $65 \%$, as is basal expression. Therefore, GAP-43 induction by each of the positive effectors tested was inhibited by dexamethasone. Furthermore, the degree of inhibition seems to be in roughly inverse proportion to inducer efficacy.
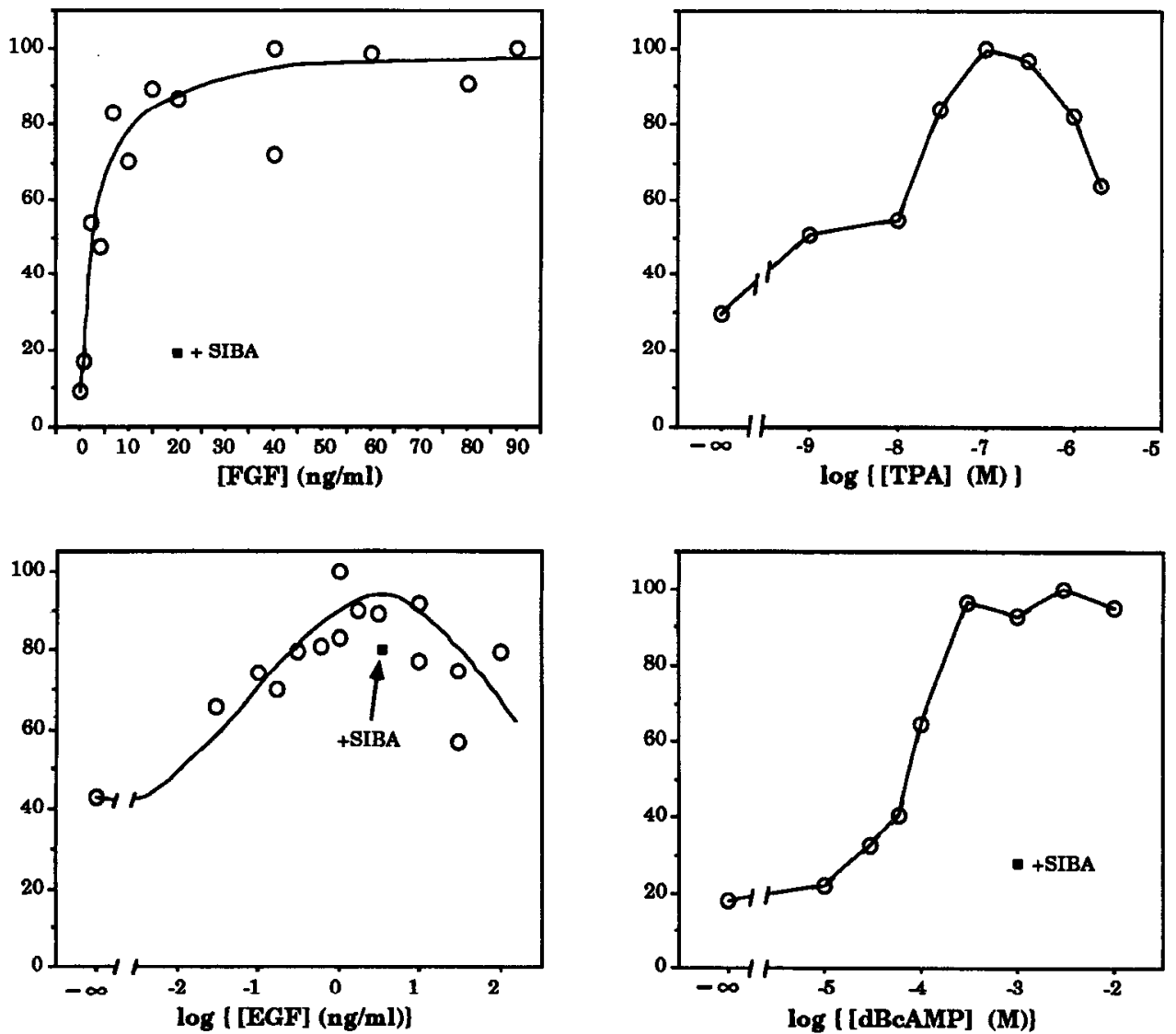

Figure 4. Dose-response relationships for FGF, EGF, TPA, and dBcAMP. Cells were treated for $24 \mathrm{hr}$ with varying concentrations of each effector (open circles). Also indicated for FGF, EGF, and ABcAMP (closed squares) is inhibition of induction by simultaneous treatment (as outlined in Fig. 1 legend) with SIBA. The effector concentrations at which SIBA inhibition was measured were: FGF $(20 \mathrm{ng} / \mathrm{ml})$, EGF ( $3 \mathrm{ng} / \mathrm{ml})$, and dBcAMP (1 mM). $Y$ axes represent relative peak areas. 


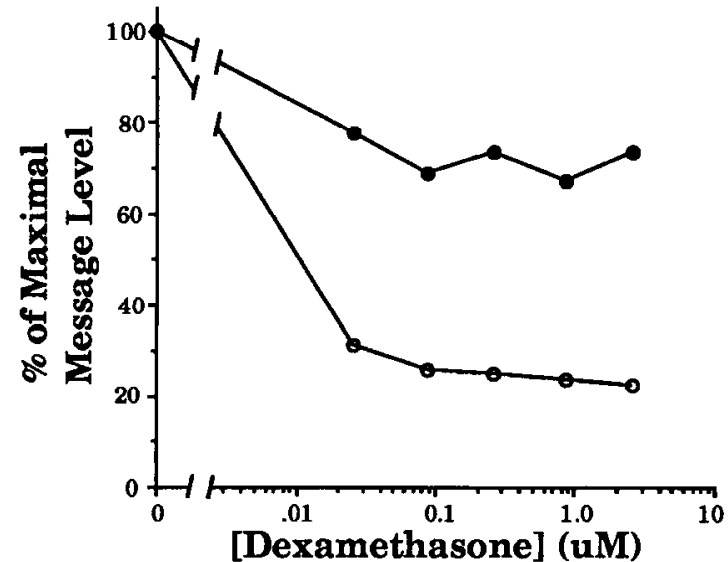

Fig. 5. Dose-response relationship for glucocorticoid inhibition of GAP43 induction by NGF. Cells were grown for $24 \mathrm{hr}$ in medium containing different concentrations of dexamethasone, followed by an additional $24 \mathrm{hr}$ in the continued presence of dexamethasone either without (open circles) or with (closed circles) $100 \mathrm{ng} / \mathrm{ml} \mathrm{NGF}$. In both cases, dexamethasone inhibition of GAP-43 RNA levels was maximal at or above $0.1 \mu \mathrm{M}$. Note that, at zero dexamethasone, the absolute GAP-43 message levels are quite different with and without NGF (see Fig. 1).

\section{Protein synthesis requirement}

The lag of almost $3 \mathrm{hr}$ before increased GAP-43 message is detected in NGF-stimulated cells (Fig. 2) suggested that protein synthesis might be a requirement for induction. To test this, we examined the effect of inhibition of protein synthesis on induction of GAP-43 message. Cells were pretreated for $2 \mathrm{hr}$ with 1 $\mu \mathrm{g} / \mathrm{ml}$ cycloheximide and then treated for another $24 \mathrm{hr}$ with various inducers in the continued presence of cycloheximide. This concentration of cycloheximide is sufficient to block $95 \%$ of incorporation of ${ }^{35} \mathrm{~S}$-methionine into cell proteins without decreasing cell survival at $26 \mathrm{hr}$ exposure (data not shown). The cycloheximide treatment decreased basal GAP-43 RNA levels and induction by all reagents tested except dBcAMP (Fig. 7). However, inhibition is never complete with any of the effectors except TPA. In that case, stimulated expression is decreased by $96 \%$, whereas for NGF and FGF, decreases are about 65 and $75 \%$, respectivcly. Hence, protein synthesis is required for full induction by NGF, FGF, and TPA but is unnecessary for induction by dBcAMP. In fact, induction by $\mathrm{dBcAMP}$ is potentiated slightly by cycloheximide.

\section{Mechanism of induction by NGF}

Both protein kinases $\mathrm{A}$ and $\mathrm{C}$ have been proposed as intracellular mediators of NGF action. The results presented thus far are consistent with these suggestions since $\mathrm{dBcAMP}$ and TPA both increase GAP-43 expression. It's unlikely that kinase A could be the sole mediator of GAP-43 induction by NGF since (1) message levels achieved with maximally effective concentrations of $\mathrm{dBcAMP}$ are below those induced by NGF, and (2) the full effect of NGF is dependent on protein synthesis, while induction by dBcAMP is essentially unaffected by inhibition of protein synthesis. The message levels achieved with TPA treatment also are far below those scen with NGF. However, as pointed out previously, these levels are probably an underestimate of TPA induction due to concomitant down-regulation of kinase C. In order to further investigate the mechanism of

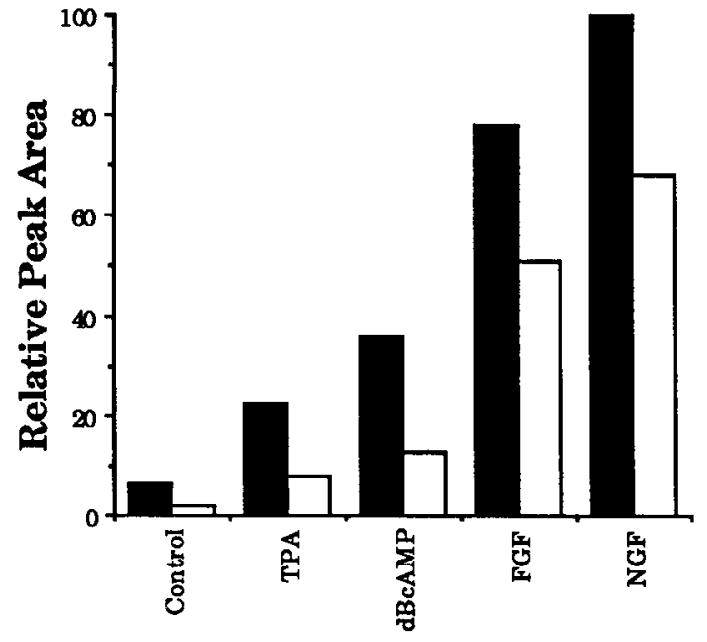

Figure 6. Glucocorticoid inhibition of GAP-43 induction by TPA, dBcAMP, FGF, and NGF. Cells were grown for $24 \mathrm{hr}$ in medium with (open bars) or without (solid bars) $1 \mu \mathrm{M}$ dexamethasone, followed by another $24 \mathrm{hr}$ in the continued presence or absence of dexamethasone plus the indicated inducer. The inducer concentrations were TPA $(0.1$ $\mu \mathrm{M}), \mathrm{dBcAMP}(1 \mathrm{mM})$, FGF $(37 \mathrm{ng} / \mathrm{ml}), \mathrm{NGF}(100 \mathrm{ng} / \mathrm{ml})$.

NGF induction of GAP-43 message, cells were treated with combinations of maximally effective doses of NGF, TPA, and dBcAMP (Fig. 8). The combined effect of TPA and dBcAMP is greater than the sum of their individual effects and matches that of NGF. This suggests that NGF could be exerting its effect via activation of both kinases $A$ and $C$. However, when cells are stimulated with TPA plus NGF, the effect is approximately additive, while dBcAMP plus NGF are more than additive. Furthermore, when TPA is added to the latter combination, its effect is approximately additive to the induction by $\mathrm{dBcAMP}$ plus NGF. The additivity of TPA plus NGF suggests independent mechanisms of induction of GAP-43. The superadditivity, or synergism, of dBcAMP when used with either or both of the other agents argues for a more complicated mechanism. Synergism of NGF and dBcAMP also has been observed in induction of ornithine decarboxylase activity (Hatanaka et al., 1978; Guroff et al, 1981) and in elevation of cellular protein and RNA levels and extcnsion of neurites in PC12 cells (Gunning et al., 1981). As a further test of kinase $C$ involvement in induction by NGF, we down-regulated this enzyme by chronic pretreatment of cells with TPA (Matthies et al., 1987). As expected, this resulted in a complete loss of TPA sensitivity (Fig. 9). However, induction by NGF was not reduced at all, and in fact, was actually enhanced by about $35 \%$. This is strong evidence against protein kinase $\mathrm{C}$ involvement in GAP-43 induction by NGF.

\section{Discussion}

In this study we have extended earlier observations on GAP43 gene control in $\mathrm{PC} 12$ cells. Of all the growth factors we examined, NGF was the most potent inducer, while insulin was without effect. Induction by NGF was independent of differences in the cell's ability to adhere to different substrates or of large differences in cell density. Both induction in response to NGF, and decay following its withdrawal were fairly rapid events, indicating tight regulatory control. FGF was almost as effective an inducer as NGF, but EGF was only slightly effective, as were 


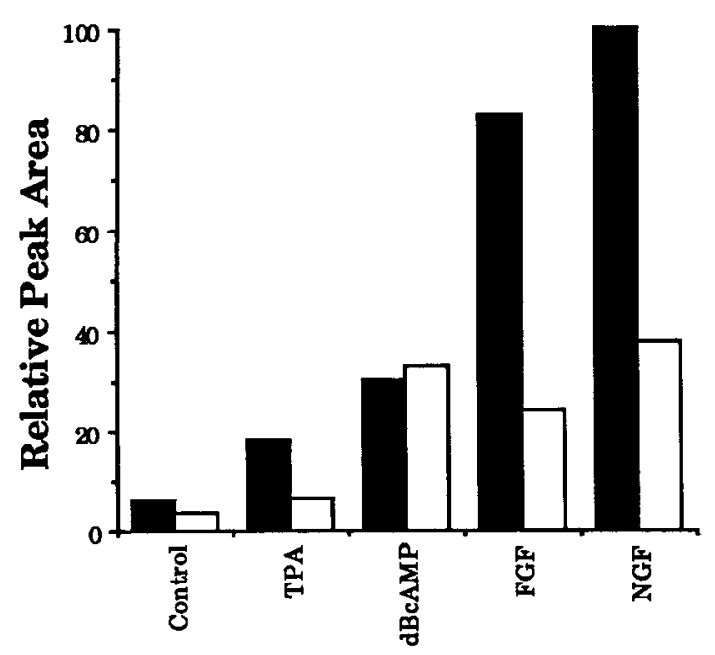

Figure 7. Effect of inhibition of protein synthesis on GAP-43 induction. Cells were grown for $2 \mathrm{hr}$ in medium with (open bars) or without (solid bars) $1 \mu \mathrm{g} / \mathrm{ml}$ cycloheximide, followed by $24 \mathrm{hr}$ in the continued presence or absence of cycloheximide plus inducer as indicated. Inducer concentrations were as in Figure 6.

dBcAMP and the phorbol ester TPA. With the exception of dBcAMP, induction by all of these effectors was decreased by inhibition of protein synthesis. Only EGF induction was unaffected by SIBA. In additivity experiments, NGF enhanced induction by TPA or ABcAMP, or TPA plus ABcAMP, while down-regulation of protein kinase $C$ by chronic treatment with TPA completely eliminated the TPA response but was without effect on NGF induction. Dexamethasone decreased basal GAP43 RNA levels and partially inhibited induction by all of the positive effectors but was far less effective in this regard than SIBA. Finally, $\mathrm{KCl}$ was slightly effective, and retinoic acid was ineffective in inducing GAP-43 message.

Since GAP-43 is presumed to be important for neurite outgrowth, it is interesting to consider how its expression is correlated with this process and whether culture conditions which influence neurite outgrowth also affect GAP-43 expression. We approached this point in 2 ways. First, we examined the effects of varying the growth substrate or cell density, parameters which influcnce neurite outgrowth in PC1 2 cells. We found that NGFinduced GAP-43 expression was independent of cell density or adhesion, and of the substrate's ability to support neurite growth. We also examined the time course of GAP- 43 expression and found that it was induced quite rapidly, such that maximal steady-state RNA levels were achieved within approximately $24 \mathrm{hr}$ exposure to NGF. It is remarkable that, by that time, very few cells have ceased division and begun to extend neurites. In fact, the response of $\mathrm{PC} 12$ cells to NGF actually includes increased proliferation within the first day of exposure (Boonstra et al., 1983). Furthermore, under the culture conditions we employed, complete cessation of cell division and initiation of morphological differentiation does not occur until about $7 \mathrm{~d}$ of NGF treatment (Greene and Tischler, 1976). This suggests that NGF is able to induce full expression of GAP-43 in cells which are still proliferating. Since morphological differentiation occurs much faster in the absence of serum, the delayed morphological response in normal serum-containing growth medium has been attributed to inhibitory serum factors (Skaper et al., 1983). Hence, if GAP-43 is necessary for neurite outgrowth in PC12 cells, it

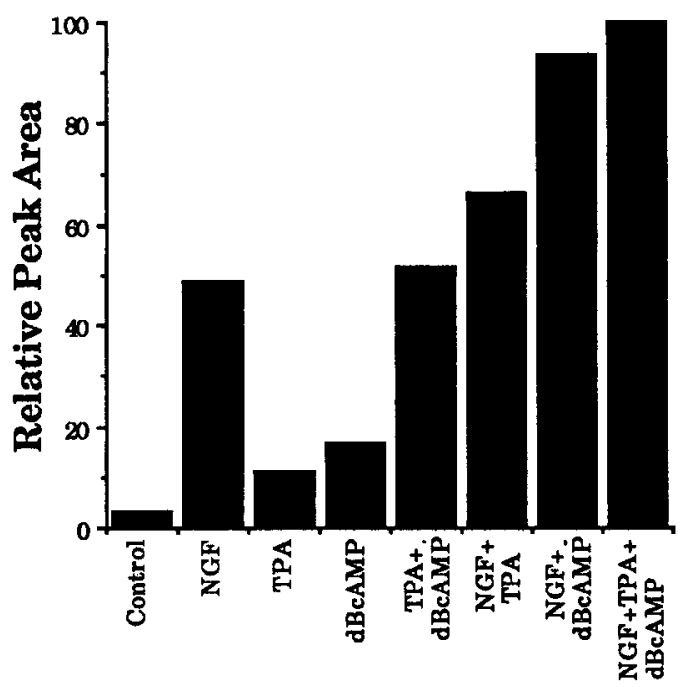

Figure 8. Combined effects of TPA, dBcAMP, and NGF on GAP-43 message. Cells were treated for $24 \mathrm{hr}$ with various combinations of maximally effective concentrations of TPA $(0.1 \mu \mathrm{M}), \mathrm{dBcAMP}(1 \mathrm{mM})$ and NGF $(100 \mathrm{ng} / \mathrm{ml})$.

evidently is not sufficient and its induction is not among the prerequisite events that are inhibited by serum. Possibly, production of one or more slowly induced gene products, such as thy-1 (Dickson et al., 1986), the neurofilament subunits (Dickson et al., 1986; Leonard et al., 1987, 1988; Lindenbaum et al., 1988 ) or proteins corresponding to the unidentified clones studied by Leonard et al. (1987) is rate limiting for NGF-induced neurite outgrowth in $\mathrm{PC} 12$ cells.

Our observation that inhibition of protein synthesis decreases induction of GAP-43 by NGF, FGF, and TPA, suggests that one or more rapid response gene products may be involved in regulating GAP-43 expression. Several such genes, including the nuclear proto-oncogenes c-fos and c-myc, as well as $\alpha$-actin and ornithine decarboxylase (Feinstein et al., 1985; Greenberg et al., 1985; Kruijer et al., 1985; Milbrandt, 1986), are transiently expressed within minutes to hours of NGF treatment. Very

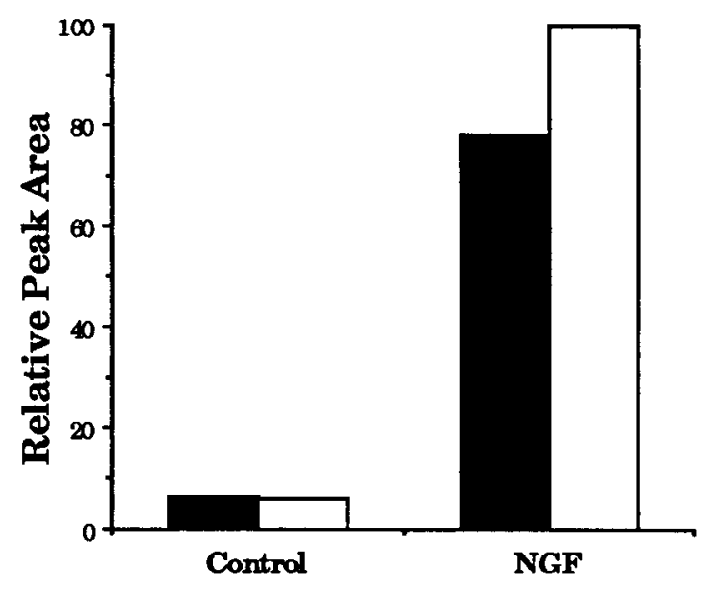

Figure 9. Effect of down-regulation of protein kinase C on NGF induction of GAP-43. Cells were treated for $3 \mathrm{~d}$ with either DMSO vehicle (solid bars) or TPA (open bars). TPA concentration was $1 \mu \mathrm{M}$ for the first $2 \mathrm{~d}$ and $0.1 \mu \mathrm{M}$ for the third day. During the third day, some cells also were treated with $100 \mathrm{ng} / \mathrm{ml} \mathrm{NGF}$ as indicated. 
recently, several additional rapid-response genes have been cloned, 2 of which, NGFI-A and NGFI-B, have been identified as putative transcription factors (Milbrandt, 1987, 1988; Cho et al., 1989). All of the reagents which we found induced GAP43 also induce c-fos in PC12 cells (Greenberg et al., 1985; Kruijer et al., 1985; Milbrandt, 1986). These observations, together with the close temporal sequence of GAP-43 induction following the transient wave of c-fos expression as observed by others, make this proto-oncogene an attractive possibility as a regulatory factor controlling GAP-43 levels during neuronal differentiation of PC12 cells. Presumably such control would be indirect since NGF does not significantly increase GAP-43 transcription in PC1 2 cells (Federoff et al., 1988). Instead, elevated transcription factor levels might effect increased expression of proteins involved in stabilization of GAP-43 message. However, we should point out in this regard that our data differ from those of Federoff et al. (1988), who found that inhibition of protein synthesis did not affect NGF induction of GAP-43 RNA. We are unable to account for this discrepancy.

The effect of SIBA on GAP-43 induction by the growth factors is consistent with previous studies. The original motivation for examining the effect of methyltransferase inhibitors on NGF actions in PC12 cells was the discovery that treatment of SCG neurons with NGF causes a rapid burst of methyl group incorporation into phospholipids (Pfenninger and Johnson, 1981). It was found that these drugs inhibit all tested responses of PC12 cells to NGF while having either no effect or enhancing responses to EGF (Seeley et al., 1984; van Calker et al., 1989). Our observations of essentially complete inhibition of NGF induction but no effect on EGF induction of GAP-43 are consistent with these earlier observations. Since, by virtually every criterion so far tested, FGF has been shown to mimic the effect of NGF on PC1 2 cells (Togari et al., 1983, 1985; Neufeld et al., 1987; Rydell and Greene, 1987), we expected, and observed that FGF vigorously induces GAP-43 and that this induction is inhibited by SIBA. The only other FGF response which has been tested and shown to be blocked by methyltransferase inhibitors in PC12 cells is neurite regeneration by primed cells (Togari et al., 1985). As discussed in detail previously (Seeley et al., 1984), the mechanism(s) by which methyltransferase inhibitors block NGF (or FGF) actions is unclear. In fact, it has been argued that inhibition of NGF actions by $S$-adenosylhomocysteine hydrolase inhibitors is unrelated to blockage of methylation reactions (Acheson and Thoenen, 1987). However, regardless of how they act, it is clear that these drugs interfere at a very early stage in the signal-transduction sequence since they block even alterations in cell surface morphology which occur within seconds of NGF exposure (Seeley et al., 1984).

Dexamethasone also inhibits GAP-43 expression. It decreased GAP-43 RNA levels in unstimulated cells and decreased induction by NGF, FGF, TPA, and dBcAMP. The opposite effects of NGF and dexamethasone on GAP-43 expression are consistent with its identification as a neuronal marker. PC12 cells generally resemble immature adrenal chromaffin cells (Greene and Tischler, 1982), and NGF and glucocorticoids have been shown to have opposite and antagonistic effects on the differentiation of such cells into either sympathetic neurons or mature chromaffin cells, respectively (Doupe et al., 1985). These agents have analogous effects on differentiation of PC12 cells into sympathetic neuron-like or mature chromaffin-like cells. Their antagonistic effects are evident in the intermediate phenotypes achieved with regard to, for instance, neurite outgrowth
(Tocco et al., 1988) or specific gene transcriptions (Leonard et al., 1987), when PC12 cells are simultaneously stimulated with both NGF and dexamethasone, as was done in our experiments. The much smaller proportional decrease of GAP-43 RNA levels by dexamethasone in cells treated with NGF (approximate 30\% decrease) compared with those in cells not treated with NGF (75\% decrease) argues for NGF's ability to antagonize glucocorticoid action. Our data suggest that this also is true for FGF. In contrast, the increased but much lower GAP-43 RNA levels in the presence of TPA or $\mathrm{dBcAMP}$ were decreased proportionately as much as were basal levels. Although the mechanism of receptor-mediated gene induction by steroid hormones such as the glucocorticoids is well understood (Yamamoto, 1985), the negative effects of steroids on gene expression have been accounted for in only a few cases. It appears that some genes may contain cis elements which differ slightly in sequence from the positive-acting glucocorticoid response element, and which mediate glucocorticoid-dependent repression (Sakai et al., 1988). In other cases, genes may contain glucocorticoid response elements which overlap with binding sites for positively-acting transcription factors and thereby inhibit transcriptional stimulation (Drouin et al., 1987; Akerblom et al., 1988). Presumably such an arrangement could account for the mutually antagonistic actions of dexamethasone and NGF with respect to GAP-43 expression. Another recent observation suggests an additional possibility for NGF antagonism of glucocorticoid action. The NGF-induced rapid response gene, NGFI-B, has strong sequence homologies to the ligand- and DNA-binding domains of several of the steroid receptors (Milbrandt, 1988). Perhaps this protein competes with the glucocorticoid receptor for DNA binding but is deficient in transcriptional activation.

Finally, we made an effort to determine the mechanism of GAP-43 induction by NGF. Increases in cAMP levels, phosphoinositide turnover and $\mathrm{Ca}_{i}^{2+}$ have all been proposed as mediators of NGF action. Our experiments suggest that protein kinase $C$ is not involved in NGF induction of GAP-43, but that kinase A could contribute to this effect. The strongest evidence against kinase $C$ involvement is that down-regulation of kinase C entirely eliminates TPA induction but, if anything, slightly increases NGF induction. Protein kinase $C$ involvement in NGFinduced neurite outgrowth and ornithine decarboxylase activity also has been ruled out based on down-regulation data (Reinhold and Neet, 1989). Additivity or superadditivity of NGF and dBcAMP effects (as we observed) have been interpreted as indications of independent mechanisms (e.g., Hatanaka et al., 1978). However, an alternative possibility suggested by our data is that, although NGF is acting partly via kinase $A$, it is not fully activating it. Hence, dBcAMP enhances this component of GAP-43 induction. In addition, the greater induction by NGF than by $\mathrm{dBcAMP}$, and their synergistic effect argue strongly for at least one cAMP-independent pathway of GAP-43 induction by NGF. This pathway might involve activation of another protein kinase, such as the recently described, NGF-regulated kinase N (Rowland et al., 1987) or an increase in eicosanoid production (DeGeorge et al., 1988). Our results suggest that an increase in intracellular $\mathrm{Ca}^{2+}$ levels also might be contributing since $\mathrm{KCl}$, which causes opening of voltage-sensitive $\mathrm{Ca}^{2+}$ channels in PCl 2 cells (Meldolesi et al., 1984; Freeman et al., 1988), also induces GAP-43. In any case, definitive information on the involvement of cAMP will require specific inhibition of kinase A. Such an approach, using PC12 sublines that are deficient in kinase $A$ activity, has substantiated earlier suggestions based on 
additivity data that NGF induction of ornithine decarboxylase is cAMP-independent (Van Buskirk et al., 1985).

GAP-43 appears to be important in neuronal growth. Its expression is regulated in a fashion very similar to that of another neuronal gene designated SCG10 (Stein et al., 1988). Both are induced by NGF in PC12 cells with a time course that is intermediate between the rapid response genes, which represent a common response of diverse cell types to both proliferative and differentiative signals, and the slower response genes, such as intermediate filament proteins, many of which, by analogy with gene expression in regenerating neurons (Perry et al., 1987), may represent structural components of growing neurites. In contrast, genes such as GAP-43 and SCG 10 are likely to be involved in processes that are uniquely important to neuronal differentiation. Studying the molecular processes underlying expression of these and other coordinately regulated genes will provide insight into determination of neuronal phenotype.

\section{References}

Acheson, A., and H. Thoenen (1987) Both short- and long-term effects of nerve growth factor on tyrosine hydroxylase in calf adrenal chromaffin cells are blocked by S-adenosylhomocysteine hydrolase inhibitors. J. Neurochem. 48: 1416-1424.

Akerblom, I. W., E. P. Slater, M. Beato, J. D. Baxter, and P. L. Mellon (1988) Negative regulation by glucocorticoids through interference with a cAMP responsive enhancer. Science 241: 350-353.

Basi, G. S., R. D. Jacobson, I. Virag, J. Schilling, and J. H. P. Skene (1987) Primary structure and transcriptional regulation of GAP-43, a protein associated with nerve growth. Cell 49: 785-791.

Benowitz, L. I., and A. Routtenberg (1987) A membrane phosphoprotein associated with neural development, axonal regeneration, phospholipid metabolism, and synaptic plasticity. Trends Neurosci. 10: 527-532.

Benowitz, L. I., V. E. Shashoua, and M. G. Yoon (1981) Specific changes in rapidly transported proteins during regeneration of the goldfish optic nerve. J. Neurosci. 1: 300-307.

Boonstra, J., W. H. Moolenaar, P. H. Harrison, P. Moed, P. T. van der Saag, and S. W. de Laat (1983) Ionic responses and growth stimulation induced by nerve growth factor and epidermal growth factor in rat pheochromocytoma (PC12) cells. J. Cell Biol. 97: 92-98.

Burton, L. E., W. H. Wilson, and E. M. Shooter (1978) Nerve growth factor in mouse saliva. Rapid isolation procedures for and characterization of $7 \mathrm{~S}$ nerve growth factor. J. Biol. Chem. 253: 7807-7812.

Chandler, C. E., and H. R. Herschman (1980) Tumor promoter modulation of epidermal growth factor- and nerve growth factor-induced adhesion and growth factor binding of PC-12 pheochromocytoma cells. J. Cell. Physiol. 105: 275-285.

Cho, K.-O., W. C. Skarnes, B. Minsk, S. Palmieri, L. Jackson-Grusby, and J. A. Wagner (1989) Nerve growth factor regulates gene expression by several distinct mechanisms. Mol. Cell. Biol. 9: 135-143.

Costello, B., and J. A. Freeman (1988) Regulation of GAP-43, a neuronal growth-associated phosphoprotein, in $\mathrm{PC1} 2$ pheochromocytoma cells. Soc. Neurosci. Abstr. 14: 1126.

Costello, B., G. J. Snipes, J. J. Norden, S. S. Bock, and J. A. Freeman (1986) Regulation and phosphorylation of the growth-associated protein, GAP-43, in NGF-stimulated PC12 cells. Soc. Neurosci. Abstr. 12: 500 .

Costello, B., J. J. Norden, and J. A. Freeman (1987) Induction and localization of the growth-associated protein, GAP-43, in NGF-stimulated PC12 cells. Soc. Neurosci. Abstr. 13: 1480.

DeGeorge, J. J., R. Walenga, and S. Carbonetto (1988) Nerve growth factor rapidly stimulates arachidonate metabolism in PC12 cells: Potential involvement in nerve fiber growth. J. Neurosci. Res. 21: 323-332.

Dickson, G., H. Prentice, J.-P. Julien, G. Ferrari, A. Leon, and F. S. Walsh (1986) Nerve growth factor activates Thy-1 and neurofilament gene transcription in rat PC12 cells. EMBO J. 5: 3449-3453.

Doupe, A. J., S. C. Landis, and P. H. Patterson (1985) Environmental influences on the development of neural crest derivatives: Glucocorticoids, growth factors, and chromaffin cell plasticity. J. Neurosci. 5: 2119-2142.
Drouin, J., J. Charron, J. P. Gagner, L. Jeannotte, M. Nemer, R. K. Plante, and O. Wrange (1987) The pro-opiomelanocortin gene: A model for negative regulation of transcription by glucocorticoids. $J$. Cell. Biochem. 35: 293-304.

Federoff, H. J., E. Grabczyk, and M. C. Fishman (1988) Dual regulation of GAP-43 gene expression by nerve growth factor and glucocorticoids. J. Biol. Chem. 263: 19290-19295.

Feinstein, S. C., S. L. Dana, L. McConlogue, E. M. Shooter, and P. Coffino (1985) Nerve growth factor rapidly induces ornithine decarboxylasc mRNA in PC12 rat pheochromocytoma cells. Proc. Natl. Acad. Sci. USA 82: 5761-5765.

Freeman, J. A., S. Bock, M. Deaton, B. McGuire, J. J. Norden, and G. J. Snipes (1986) Axonal and glial proteins associated with development and response to injury in the rat and goldfish optic nerve. In Recovery from Neural Trauma, G. Gilad and M. Schwartz, eds., pp. 34-47, Springer-Verlag, Berlin.

Freeman, J. A., A. A. Lettes, and B. Costello (1988) Possible role of GAP-43 in calcium regulation/transmitter release. Soc. Neurosci. Abstr. 14: 1126.

Greenberg, M. E., L. A. Greene, and E. B. Ziff (1985) Nerve growth factor and epidermal growth factor induce rapid transient changes in proto-oncogene transcription in PC12 cells. J. Biol. Chem. 260: 1410114110.

Greene, L. A., and A. S. Tischler (1976) Establishment of a noradrenergic clonal line of rat adrenal pheochromocytoma cells which respond to nerve growth factor. Proc. Natl. Acad. Sci. USA 73: 2424 2428.

Greene, L. A., and A. S. Tischler (1982) PC12 pheochromocytoma cultures in neurobiological research. In Advances in Cellular Neurobiology, Vol. 3, S. Federoff and L. Hertz, eds., pp. 373-414, Academic, New York.

Gunning, P. W., P. C. Letourneau, G. E. Landreth, and E. M. Shooter (1981) The action of nerve growth factor and dibutyryl adenosine cyclic $3^{\prime}: 5^{\prime}$-monophosphate on rat pheochromocytoma reveals distinct stages in the mechanisms underlying neurite outgrowth. J. Neurosci. 1: 1085-1095.

Guroff, G., G. Dickens, and D. End (1981) The induction of ornithine decarboxylase by nerve growth factor and cpidcrmal growth factor in PC12 cells. J. Neurochem. 37: 342-349.

Hatanaka, H., U. Otten, and H. Thoenen (1978) Nerve growth factormediated selective induction of ornithine decarboxylase in rat pheochromocytoma: A cyclic AMP-independent process. FEBS Lett. 92: 313-316.

Jacobson, R. D., I. Virag, and J. H. P. Skene (1986) A protein associated with axon growth, GAP-43, is widely distributed and developmentally regulated in rat CNS. J. Neurosci. 6: 1843-1855.

Jolles, J., H. Zwiers, C. J. van Dongen, P. Schotman, K. W. A. Wirtz, and W.H. Gispen (1980) Modulation of brain polyphosphoinositide metabolism by ACTH-sensitive protein phosphorylation. Nature 286 : 623-625.

Karns, L. R., S.-C. Ng, J. A. Freeman, and M. C. Fishman (1987) Cloning of complementary DNA for GAP-43, a ncuronal growthrelated protein. Science 236:597-600.

Kruijer, W., D. Schubert, and I. M. Verma (1985) Induction of the proto-oncogene fos by nerve growth factor. Proc. Natl. Acad. Sci. USA $82: 7330-7334$.

Landreth, G. E., and E. M. Shooter (1980) Nerve growth factor receptors on PC1 2 cells: Ligand-induced conversion from low- to highaffinity states. Proc. Natl. Acad. Sci. USA 77: 4751-4755.

Leonard, D. G. B., E. B. Ziff, and L. A. Greene (1987) Identification and characterization of mRNAs regulated by nerve growth factor in PC12 cells. Mol. Cell. Biol. 7: 3156-3167.

Leonard, D. G. B., J. D. Gorham, P. Cole, L. A. Greene, and E. B. Ziff (1988) A nerve growth factor-regulated messenger RNA encodes a new interfilament protein. J. Cell Biol. 106: 181-193.

Lindenbaum, M. H., S. Carbonetto, F. Grosvcld, D. Flavell, and W. E. Mushynski (1988) Transcriptional and post-transcriptional effects of nerve growth factor on expression of the three neurofilament subunits in PC-12 cells. J. Biol. Chem. 263: 5662-5667.

Matthies, H. J. G., H. C. Palfrey, L. D. Hirning, and R. J. Miller (1987) Down regulation of protein kinase $\mathrm{C}$ in neuronal cells: Effects on neurotransmitter release. J. Neurosci. 7: 1198-1206.

McGuire, C. B., G. J. Snipes, and J. J. Norden (1988) Light-microscopic immunolocalization of the growth- and plasticity-associated protein GAP-43 in the developing rat brain. Brain Res. 41: 277-291. Meiri, K. F., K. H. Pfenninger, and M. B. Willard (1986) Growth- 
associated protein, GAP-43, a polypeptide that is induced when neurons extend axons, is a component of growth cones and corresponds to $\mathrm{pp} 46$, a major polypeptide of a subcellular fraction enriched in growth cones. Proc. Natl. Acad. Sci. USA 83: 3537-3541.

Meiri, K. F., M. Willard, and M. I. Johnson (1988) Distribution and phosphorylation of the growth-associated protein GAP-43 in regencrating sympathetic neurons in culture. J. Neurosci. 8: 2571-2581.

Meldolesi, J., W. B. Huttner, R. Y. Tsien, and T. Pozzan (1984) Free cytoplasmic $\mathrm{Ca}^{2+}$ and neurotransmitter release: Studies on PC12 cells and synaptosomes exposed to a-latrotoxin. Proc. Natl. Acad. Sci. USA 81: $620-624$.

Milbrandt, J. (1986) Nerve growth factor rapidly induces c-fos mRNA in PC12 rat pheochromocytoma cells. Proc. Natl. Acad. Sci. USA 83: 4789-4793.

Milbrandt, J. (1987) A nerve growth factor-induced gene encodes a possible transcriptional regulatory factor. Science 238: 797-799.

Milbrandt, J. (1988) Nerve growth factor induces a gene homologous to the glucocorticoid receptor gene. Neuron $1: 183-188$

Morrison, R. S., A. Sharma, J. De Vellis, and R. A. Bradshaw (1986) Basic fibroblast growth factor supports the survival of cerebral cortical neurons in primary culture. Proc. Nat1. $\Lambda$ cad. Sci. US $\Lambda$ 83: $7537-$ 7541 .

Neufeld, G., D. Gospodarowicz, L. Dodge, and D. K. Fujii (1987) Heparin modulation of the neurotropic effects of acidic and basic fibroblast growth factors and nerve growth factor on PC12 cells. J. Cell. Physiol. 131: 131-140.

Neve, R. L., N. I. Perrone-Bizzozero, S. Finkelstein, H. Zwiers, E. Bird, D. M. Kurnit, and L. I. Benowitz (1987) The neuronal growthassociated protein GAP-43 (B-50, F-1): Neuronal specificity, developmental regulation and regional distribution of the human and rat mRNAs. Mol. Brain Res. 2: 177-183.

Nielander, H. B., L. H. Schrama, A. J. Van Rosen, M. Kasperaitis, A. B. Oestreicher, P. N. E. DeGrann, W. H. Gispen, and P. Schotman (1987) Primary structure of the neuron-specific phosphoprotein B-50 is identical to growth-associated protein GAP-43. Neurosci. Res. Commun. 1: 163-172.

Nishizuka, Y. (1984) The role of protein kinase C in cell surface signal transduction and tumour promotion. Nature 308: 693-698.

Perrone-Bizzozero, N. I., S. P. Finkelstein, and L. I. Benowitz (1986) Synthesis of a growth-associated protein by embryonic rat cerebrocortical neurons in vitro. J. Neurosci. 6: 3721-3730.

Perry, G. W., D. W. Burmeister, and B. Grafstein (1987) Fast axonally transported proteins in regenerating goldfish optic axons. J. Neurosci. 7: 792-806.

Pfenninger, K. H., and M. P. Johnson (1981) Nerve growth factor stimulates phospholipid methylation in growing neurites. Proc. Nat1. Acad. Sci. USA 78: 7797-7800.

Reinhold, D. S., and K. E. Neet (1989) The lack of a role for protein kinase $\mathrm{C}$ in neurite extension and in the induction of ornithine decarboxylase by nerve growth factor in PC1 2 cells. J. Biol. Chem. 264: 3538-3544.

Rosenthal, A., S. Y. Chan, W. Henzel, C. Haskell, W.-J. Kuang, E. Chen, J. N. Wilcox, A. Ullrich, D. V. Goeddel, and A. Routtenberg (1987) Primary structure and mRNA localization of protein F1, a growth-related protein kinase $\mathrm{C}$ substrate associated with synaptic plasticity. EMBO J. 6: 3641-3646.

Rowland, E. A., T. H. Muller, M. Goldstein, and L. A. Greene (1987) Cell-free detection and characterization of a novel nerve growth factor-activated protein kinase in PC12 cells. J. Biol. Chem. 262: 75047513.

Routtenberg, A., D. M. Lovinger, and O. Steward (1985) Selective increase in phosphorylation of a $47 \mathrm{kDa}$ protein $(\mathrm{F} 1)$ directly related to long-term potentiation. Behav. Neural Biol. 43: 3-11.

Rydell R. E., and L. A. Greene (1987) Acidic and basic fibroblast growth factors promote stable neurite outgrowth and neuronal differentiation in cultures of PC12 cells. J. Neurosci. 7: 3639-3653.

Sakai, D. D., S. Helms, J. Carlstedt-Duke, J. A. Gustafsson, F. M. Rottman, and K. R. Yamamoto (1988) Hormone-mediated repression of transcription: A negative glucocorticoid response element from the bovine prolactin gene. Genes Dev. 2: 1144-1154.
Seeley, P. J., A. Rukenstein, J. L. Connolly, and L. A. Greene (1984) Differential inhibition of nerve growth factor and epidermal growth factor effects on the PC12 pheochromocytoma line. J. Cell Biol. 98: $417-426$

Skaper, S. D., I. Selak, and S. Varon (1983) Serum- and substratumdependent modulation of neuritic growth. J. Neurosci. Res. 9: 359369.

Skene, J. H. P. (1989) Axonal growth-associated proteins. Annu. Rev. Neurosci. 12: 127-156.

Skene, J. H. P., and K. Kalil (1984) A "growth-associated protein" (GAP-43) in developing and severed axons of the hamster pyramidal tract. Soc. Neurosci. Abstr. 10: 1030.

Skene, J. H. P., and M. Willard (1981a) Changes in axonally transported proteins during axon regeneration in toad retinal ganglion cells. J. Cell Biol. 89: 86-95.

Skene, J. H. P., and M. Willard (1981b) Axonally transported proteins associated with axon growth in rabbit central and peripheral nervous systems. J. Cell Biol. 89: 96-103.

Snipes, G. J., S. Y. Chan, C. B. McGuire, B. R. Costello, J. J. Norden, J. A. Freeman, and A. Routtenberg (1987a) Evidence for the coidentification of GAP-43, a growth-associatcd protein, and F1, a plasticityassociated protein. J. Neurosci. 7: 4066-4075.

Snipes, G. J., B. Costello, C. B. McGuire, B. N. Mayes, S. S. Bock, J. J. Norden, and J. A. Freeman (1987b) Regulation of specific neuronal and non-neuronal proteins during development and following injury in the rat CNS. Prog. Brain Res. 71: 155-175.

Stein, R., S. Orit, and D. J. Anderson (1988) The induction of a neuralspecific gene, SCG10, by nerve growth factor in PC12 cells is transcriptional, protein synthesis dependent, and glucocorticoid inhibitable. Dev. Biol. 127: 316-325.

Tocco, M. D., M. L. Contreras, S. Koizumi, G. Dickens, and G. Guroff (1988) Decreased levels of nerve growth factor receptor on dexamethasone-treated PC12 cells. J. Neurosci. Res. 20:41 1-419.

Togari, A., D. Baker, G. Dickens, and G. Guroff (1983) The neuritepromoting effect of fibroblast growth factor on PC1 2 cells. Biochem. Biophys. Res. Commun. 114: 1189-1193.

Togari, A., G. Dickens, H. Kuzuya, and G. Guroff (1985) The effect of fibroblast growth factor on PC1 2 cells. J. Neurosci. 5: 307-316.

Van Buskirk, R., T. Corcoran, and J. A. Wagner (1985) Clonal variants of PC12 pheochromocytoma cells with defects in cAMP-dependent protein kinase induce ornithine decarboxylase in response to nerve growth factor but not to adenosine agonists. Mol. Cell. Biol. 5: 1984-1992.

van Calker, D., K. Takahata, and R. Heumann (1989) Nerve growth factor potentiates the hormone-stimulated intracellular accumulation of inositol phosphates and $\mathrm{Ca}^{2+}$ in rat $\mathrm{PC} 12$ pheochromocytoma cells: Comparison with the effect of epidermal growth factor. J. Neurochem. 52: $38-45$.

Van Hoof, C. O. M., P. N. E. De Gran, J. Boonstra, A. B. Oestreicher, M. H. Schmidt-Michels, and W. H. Gispen (1986) Nerve growth factor enhances the level of the protein kinase $C$ substrate B-50 in pheochromocytoma PC12 cells. Biochem. Biophys. Res. Commun. 139: 644-651.

Van Hoof, C. O. M., P. N. E. De Gran, A. B. Oestreicher, and W. H. Gispen (1988) B-50 phosphorylation and polyphosphoinositide metabolism in nerve growth cone membranes. J. Neurosci. 8: 17891795.

Walicke, P. (1988) Basic and acidic fibroblast growth factors have trophic effects on neurons from multiple CNS regions. J. Neurosci. 8: 2618-2627.

Walicke, P., W. M. Cowan, N. Ueno, A. Baird, and R. Guillemin (1986) Fibroblast growth factor promotes survival of dissociated hippocampal neurons and enhances neurite extension. Proc. Natl. Acad. Sci. USA 83: 3012-3016.

Walsh, D., J. P. Perkins, and E. Krebs (1968) An adenosine 3',5'monophosphate-dependent protein kinase from rabbit skeletal muscle. J. Biol. Chem. 243: 3763-3774.

Yamamoto, K. R. (1985) Steroid receptor regulated transcription of specific genes and gene networks. Annu. Rev. Genet. 19: 209-252. 